\title{
Modeling the effects of Urban Growth Scenarios on Water Demand and Runoff Patterns in Dublin, Ireland
}

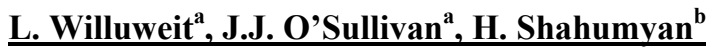 \\ ${ }^{a}$ School of Civil, Structural and Environmental Engineering, University College Dublin \\ ${ }^{b}$ School of Geography, Planning and Environmental Policy, University College Dublin \\ Email: lars.willuweit@ucdconnect.ie
}

\begin{abstract}
The concept of sustainable urban water management involves managing the urban water cycle in a holistic manner by integrating the water supply, wastewater and stormwater management of a city to achieve better assimilation of the urban and natural water cycles.

In response to the emergence to this new paradigm, decision support models have been developed to facilitate integrated modeling of the urban water cycle and to provide functionality for comparing options for alternative water management options. Outputs typically include indicators such as whole life costs, water flow indicators and energy use. Available models however have shortcomings and tend to have limited capacity to incorporate urban land use changes and the significant but related effects that different urbanization scenarios will have on the urban water cycle.
\end{abstract}

Against this background, the Dynamic Urban Water Simulation Model (DUWSiM) has been developed. DUWSiM is a computer based model that links a cellular automata land use dynamics model (MOLAND) with concepts from existing water balance models. DUWSiM simulates major components of the urban water cycle including, evaporation, runoff, water demand, water supply and wastewater on a daily time step and incorporates urban land use change scenarios on an annual basis for 20 years into the future.

DUWSiM has been applied to the Greater Dublin Water Supply area in Ireland to assess the effects of four urban development scenarios based on regional planning policies on water demand and stormwater runoff from 2007 - 2026. It was shown that significant differences in water demand and stormwater runoff exist between urban planning scenarios and it was concluded that urban planners and urban water managers need to collaborate in order to develop effective long-term strategies for the urban water sector.

The scenarios assessed were all based on the same population and economic projections and all assumed low and medium density development of urban fabric. Future research should assess the combined effects of regional planning policies, population and economic projections, climate change and urban form (low density vs. high density/compact development) on the urban water cycle.

Keywords: $\quad$ Runoff, Water Demand, Urbanization, Urban Growth, Urban Water Management 
Willuweit et al., Modeling the effects of urban growth scenarios on water demand and runoff patterns in Dublin, Ireland

\section{INTRODUCTION}

The global population is expected to increase from its current level of 7 billion to 9.2 billion by 2050 (UN, $2010)$, leading to an estimated increase in global water demand of 55\% (OECD, 2012). In the same time period, the urban population is expected to increase from 3.6 billion to 6.3 billion (UN, 2012). Together with unprecedented economic development, this is likely to lead to a doubling of the urban water demand by 2025 (UNEP, 2008). These effects, in combination with global climate change, will continue to stress the critical urban water infrastructures and, as suggested by Niemczynowicz (1999) and Pataki et al. (2011), will lead to cities facing ever increasing challenges in effectively managing their water resources.

Against this background, the Dynamic Urban Water Simulation Model (DUWSiM) was developed. DUWSiM links urban water cycle concepts to the MOLAND land use dynamics model (e.g. Engelen et al., 2007; Shahumyan et al., 2009)) and the LARS-WG weather generator (Racsko, Szeidl, \& Semenov, 1991; M. A. Semenov \& Barrow, 1997) and allows modeling the effects of urban development scenarios and climate change scenarios on the urban water cycle.

This paper presents the application of DUWSiM to the Greater Dublin Water Supply Area (GDWSA) in Ireland to assess the effects of four regional development scenarios on urban water demand and resulting water production costs, and runoff patterns. The next section will introduce the DUWSiM model, followed by an introduction of the GDWSA and the development scenarios used for this study. Finally, the results and their implications are presented.

\section{THE DYNAMIC URBAN WATER SIMULATION MODEL (DUWSIM)}

The model structure, components, algorithms as well as the calibration and validation of DUWSiM are provided in Willuweit and O'Sullivan (in press). A brief introduction of DUWSiM is presented here. DUWSiM is an integrated simulation model consisting of a climate model (LARS-WG), a land use dynamics model (MOLAND) and an urban water balance model (DUWSiM-WB). By incorporating the changing impacts on the urban land fraction from urban development and changing precipitation and evaporation patterns from climatic changes, DUWSiM acts as an integrated modeling framework that models the effects of urbanization and climate change scenarios on urban water processes (Figure 1).

DUWSiM simulates major components of the urban water cycle such as runoff, water demand, water supply and wastewater on a daily time step. It incorporates urban land use change and climate change scenarios on an annual basis for up to 20 years into the future.

The model has two potential roles in urban water management. Firstly, in the context of different urban growth and climate scenarios, the model can predict the likely changes in water demand, wastewater discharge and stormwater runoff. Secondly, the model can facilitate assessment of potential water supply and demand management options on the sustainability of the water system, again in the context of urbanization and climate scenarios. The model offers the added advantage of allowing comparison of water management options based on recognized sustainability indicators such as whole life costs and energy, water demand, available supply and wastewater production.

\subsection{Modeling Urban Land Use Changes}

In DUWSiM, urban land use changes are modeled by the cellular automata-based land use dynamics model MOLAND (Engelen et al. 2007). MOLAND works on a macro and a micro level (Shahumyan et al., 2009). On the macro level, the model takes as input population projections and job market projections by economic sector in a region. On the micro level, population growth and economic activities are translated into a number of land uses. As shown in Figure 2, the study region is represented by a grid layout (of four hectares resolution), each cell representing a parcel of land of a particular land use type. For example, the population is provided for within residential land use type cells and the economic activity is provided for within commercial and industrial land use type cells.

During simulation, MOLAND runs a cellular automata algorithm to identify the statistically most likely development pattern of the study region based on the model inputs. Figure 2 shows the actual land use in 2006 and the simulated model output for 2026 for the Dublin Region. The simulated land use, consisting of an array of land use cells each with an associated land use type, for each year of the modeling period is converted to ASCII format and transferred to the DUWSiM database. This output is subsequently used as an input to DUWSiM-WB, as shown by the arrows between MOLAND and the DUWSiM database and the DUWSiM database and DUWSiM-WB in Figure 1. 
Willuweit et al., Modeling the effects of urban growth scenarios on water demand and runoff patterns in Dublin, Ireland

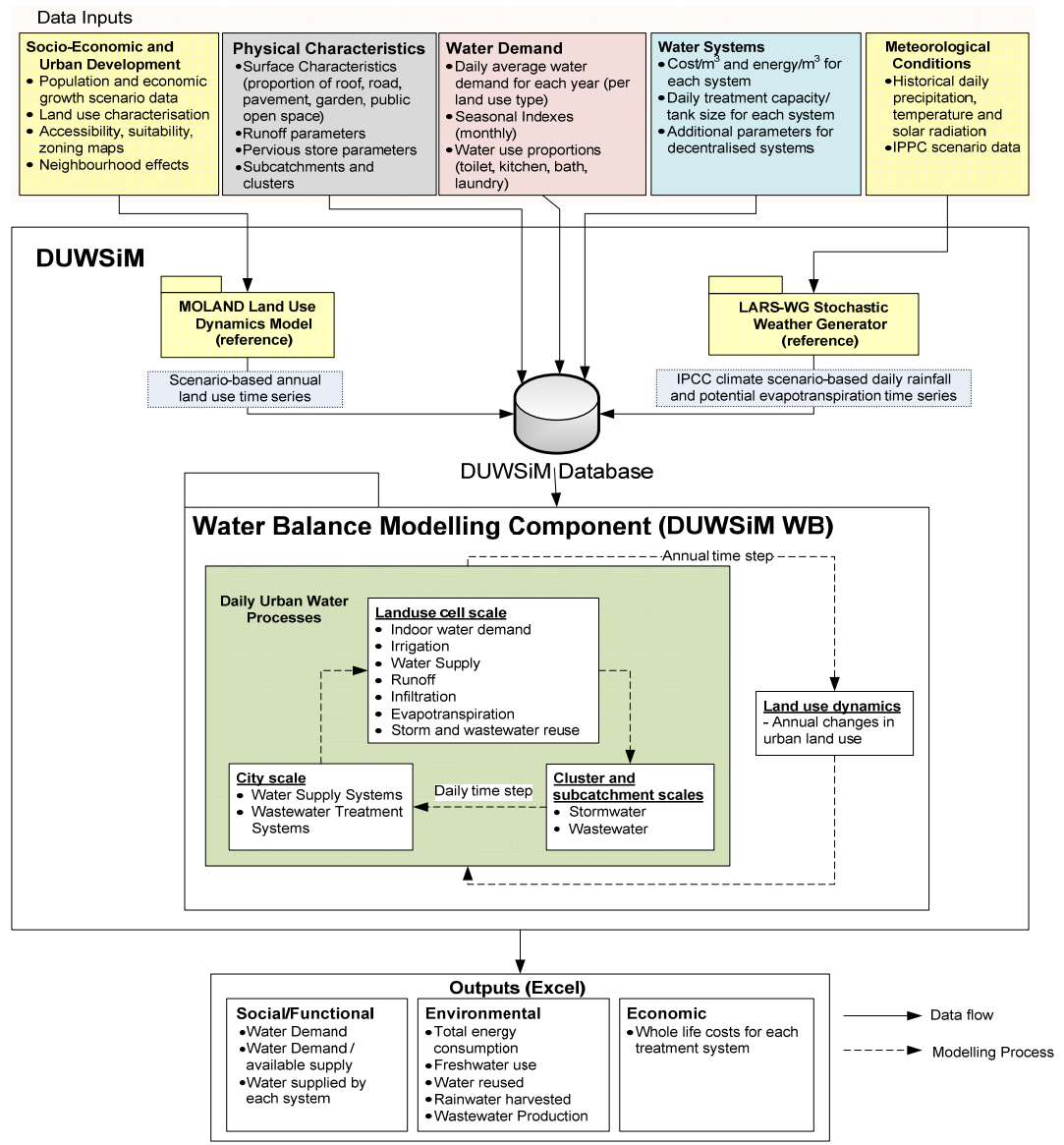

Figure 1: Main components and data flows of DUWSiM

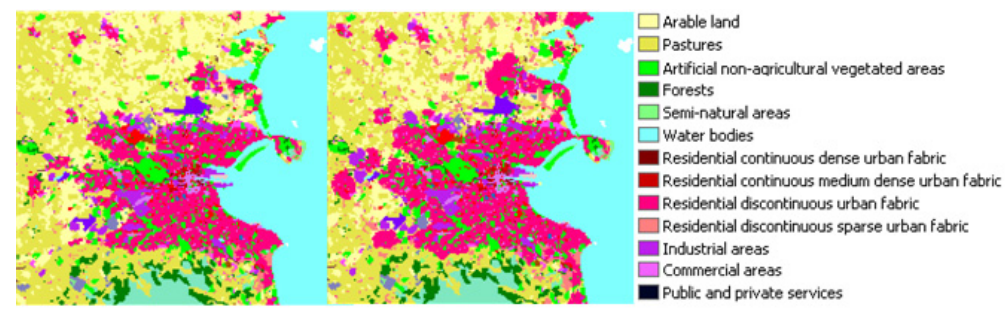

Figure 1: MOLAND representation of actual land use in Dublin in 2006 and simulated land use in 2026

\subsection{Generating Climate Scenarios with LARS-WG}

LARS-WG is a model which, after calibration of site parameters with historical observed weather, simulates synthetic time series of daily weather that are statistically similar to observed weather (M. Semenov \& Stratonovitch, 2010). Inputs of LARS-WG include long-term historical daily time series of precipitation, temperature and solar radiation. Outputs include daily rainfall and potential evapotranspiration which are stored on the DUWSiM database and forms the climate data input to DUWSiM-WB (Figure 1).

By perturbing the parameters of LARS-WG using predicted climate change scenarios from Global Climate Models (GCMs), LARS-WG enables the user to generate synthetic daily weather data for potential future climates. It therefore has the capability to statistically downscale low-resolution future climate predictions from GCMs to local daily weather time series.

\subsection{Modelling the Urban Water Cycle with DUWSiM-WB}

DUWSiM-WB is a nested model that integrates the land use and climate predictions from MOLAND and LARS-WG with urban water cycle processes to model the effects of urban and climatic change scenarios on the urban water cycle. As shown by the outer (annual) and inner (daily) loops in Figure 1, DUWSiM-WB runs on two time steps; a daily time step and an annual time step. All water related processes such as water 
Willuweit et al., Modeling the effects of urban growth scenarios on water demand and runoff patterns in Dublin, Ireland

supply, storm and wastewater flows, irrigation, precipitation, evapotranspiration, and infiltration are modelled on a daily basis. Land use changes are accounted for on an annual basis. DUWSiM-WB has been developed using the C-Sharp programming language and emphasis was placed on user-friendlines. Based on the objective-oriented philosophy, DUWSiM-WB is highly modular, facilitating development of additional functionality.

DUWSiM was applied to Dublin, the capital of Ireland, for assessing the effects of four development scenarios on water demand and storm water runoff patterns. The case of Dublin is introduced in the following section.

\section{THE DUBLIN REGION WATER SUPPLY AREA}

The Dublin Region Water Supply Area (DRWSA), located on the east coast of Ireland, has a population of approximately 1.5 million (CSO, 2012) and is divided into the administrative regions of Dublin City, South Dublin, Dun Laoghaire Rathdown and Fingal and parts of Meath, Wicklow and Kildare (Figure 3). As shown in figure 3, a distinction is made between the GDWSA and the Greater Dublin Region (GDR, which includes all of Meath, Wicklow, Kildare and Louth). The GDWSA contains most of the urban area within the GDR, whereas the remainder of the region consists mostly of greenfield areas such as pastures and highly dispersed low density residential areas. The GDWSA is characterized by a relatively flat topography with an annual average rainfall of about $700 \mathrm{~mm}$ and average temperatures of about 6 degrees in winter and 15 degrees in summer. Most of the population is spread out in medium to low density residential areas with high density areas not common, making Dublin a city with a high proportion of garden area and public open space.

The region has experienced rapid urban expansion resulting from the 'Celtic Tiger' era in the 1990s and early 2000 s. This was followed by an ongoing economic downturn as of the late 2000s. The development pattern of the region was economically driven and developer led leading to relatively unmanaged urban sprawl. As the urban fabric expanded, increasing pressure was placed on urban water supply, wastewater and storm water infrastructure (DCC, 2010; GDSDS, 2005). While expansion of current water infrastructure systems is ongoing, the systems are approaching their capacity limits. For example, the Dublin region has existing water sources of approximately $625 \mathrm{Ml} / \mathrm{d}$ and current water demand of the area varies between 575 and $625 \mathrm{Ml} / \mathrm{d}$ (DCC, 2010).
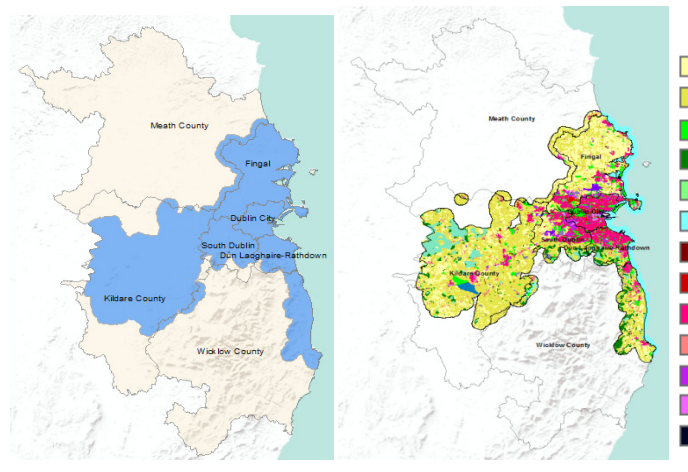

$\square$ Arable land

$\square$ Pastures

$\square$ Artificial non-aqricultural vegetated areas

Forests

$\square$ Semi-natural areas

$\square$ Water bodies

Residential continuous dense urban fabric

Residential continuous medium dense urban fabric

Residential discontinuous urban fabric

$\square$ Residential discontinuous sparse urban fabric

Industrial areas

Commercial areas

Public and private services

\section{Figure 3: The Greater Dublin Water Supply Area (left) and its representation in MOLAND (right)}

\subsection{Land Use Scenarios}

In order to assess the effects of land use policies on urban development patterns for the Greater Dublin Region (GDR), four scenarios based on the Regional Planning Guidelines (RPGs) of the GDR were translated to MOLAND scenarios (Brennan et al., 2009; RPGO, 2010; Shahumyan et al., 2009). These scenarios were used in DUWSiM to assess their effects on urban water demand and runoff patterns within the GDWSA and are introduced below.

In light of the ongoing economic downturn, all scenarios use a low population projection and are a representation of differing urban planning policies rather than differing socio-economic scenarios.

\section{Scenario 1: Continued Trends}

Scenario 1 explores a continuation of the current, dispersed settlement patterns. Figure 4 clearly shows a more dispersed development compared to the remaining scenarios. Although both Strategic Planning Guidelines (SPGs) for the GDA in 1999 and the subsequent Regional Planning Guidelines in 2004 
Willuweit et al., Modeling the effects of urban growth scenarios on water demand and runoff patterns in Dublin, Ireland

emphasized a move toward a consolidated settlement pattern, strong green belt policy and improved transport links (DELG, 2002; DRAMERA, 1999), it has been suggested that there has been a divergence between policy and practice (Convery, McInerney, Sokol, \& Stafford, 2006). Scenario 1 therefore simulates a "business as usual" future, whereby implementation of the planning guidelines has been weak in places (Brennan et al., 2009).

\section{Scenario 2: Finger Expansion}

This scenario explores the effects of a policy of consolidation (Brennan et al., 2009). Development is strongly directed toward an expanded metropolitan area, which is extended along key transport corridors. New transport routes are developed and strictly enforced strategic green belts are used to discourage development in rural areas. Since the theme of this scenario is to focus development in an expanded metropolitan area and along key corridors, large green belts were placed between the major roads to encourage development along transport links leading to a 'finger' shaped expansion (Figure 4).

\section{Scenario 3: Consolidation of Key Towns \& Metropolitan Area}

Scenario 3 simulates the original spatial planning guidelines from 1999 where future development was to be consolidated within the existing Metropolitan Area and development centers along major transport routes (DRAMERA, 1999). This scenario explores a strong consolidation policy, whereby growth is focused within the existing Metropolitan Area and towards a limited number of key towns in the Hinterland (Brennan et al., 2009).

\section{Scenario 4: Managed Dispersal}

In Scenario 4 consolidation is once again promoted and development is focused within the existing metropolitan area and development centers. Growth at public transport nodes within the metropolitan area and in designated towns on high quality public transport routes is promoted. Although consolidation within the existing metropolitan area was a focus of this scenario, there was a drive to keep towns distinct from one another (Brennan et al., 2009).

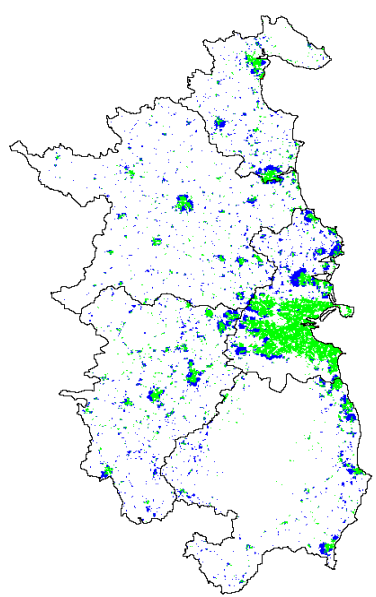

Scenario1: Continued Trends

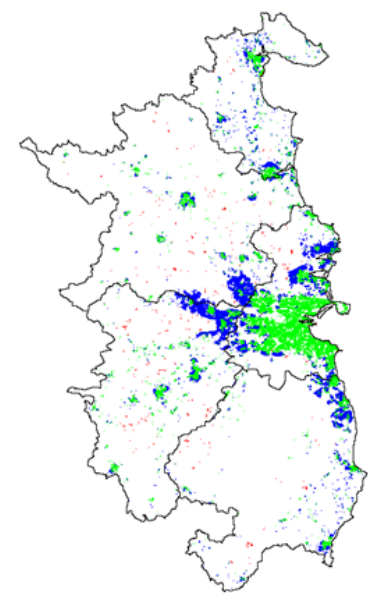

Scenario 2: Finger Expansion

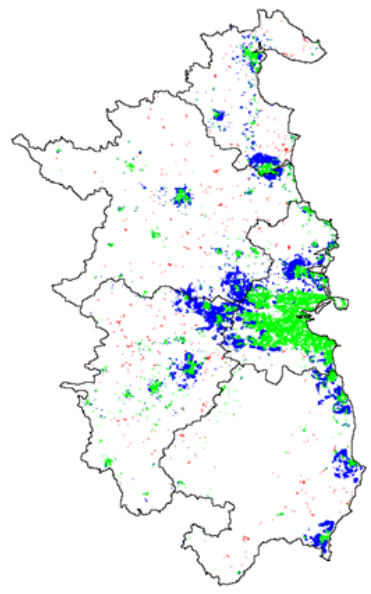

Scenario 3: Consolidation of Key Towns and Metropolitan area

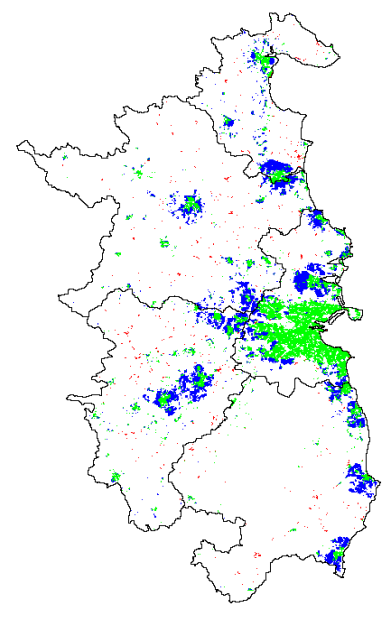

Scenario 4: Managed Dispersal

Figure 4: MOLAND simulation results for the 4 scenarios where green areas represent actual urban fabric in 2006 and blue represents predicted changes in 2026. Note: This figure shows the whole GDA whereas the present study only models water demand and runoff in the GDWSA as shown in figure 3

\section{RESULTS}

DUWSiM has been calibrated for Dublin with Nash-Sutcliffe coefficients of 0.95 and 0.42 for runoff and water demand respectively for the validation period. While the coefficient of 0.42 is not high, DUWSiM simulated water demand with an accuracy of better than $4 \%$ during the validation period $(2007-2012)$. Due to Dublin's climate, it is assumed that irrigation is negligible as long dry and warm periods are rare. 
Willuweit et al., Modeling the effects of urban growth scenarios on water demand and runoff patterns in Dublin, Ireland

\subsection{Water demand response and whole life cost implications of land-cover change scenarios}

Average daily water demand was about $550 \mathrm{Ml} / \mathrm{d}$ in 2006. Figure 5 shows the simulation results for the period of 2007 - 2026 for the four scenarios. Assuming that current per capita consumption patterns remain unchanged, DUWSiM predicts an increase in water demand of 41.5, 50.1, 50.4 and 49.5\% for scenario 1,2,3 and 4 respectively by 2026 . Scenario 1 results in the lowest water demand prediction for the GDWSA yielding a water demand of 6-7\% (approx. $50 \mathrm{Ml}$ ) less than the other scenarios. Scenario 1 assumes dispersed development, resulting in continued low density development in the hinterland outside of the water supply area thus leading to a less centralized demand and relieving the demand pressure on the GDWSA. The remaining scenarios all result in similar water demand projections with the largest difference between scenario 3 and 4 ( $0.6 \%$ difference). Again, this difference is caused by increased development outside of the GDWSA (although far less pronounced than in scenario 1).

At the time of writing there is only limited data available on cost and energy demand for water treatment in Dublin. However, it has been estimated that the average unit production cost of water in Ireland, including abstraction, treatment, distribution and treatment of byproducts, is about $1 € / \mathrm{m}^{3}$ (DOEHLG, 2006). This means that by 2026, scenario 1 (total estimated annual cost based on 2026 predicted demand: $273.8 \mathrm{~m} €$ ) will lead to approximately $18.3 \mathrm{~m} €$ less annual expenditure for water production in the GDWSA compared to scenarios 2-4 (total estimated cost in 2026: about $292 \mathrm{~m} €$ ).

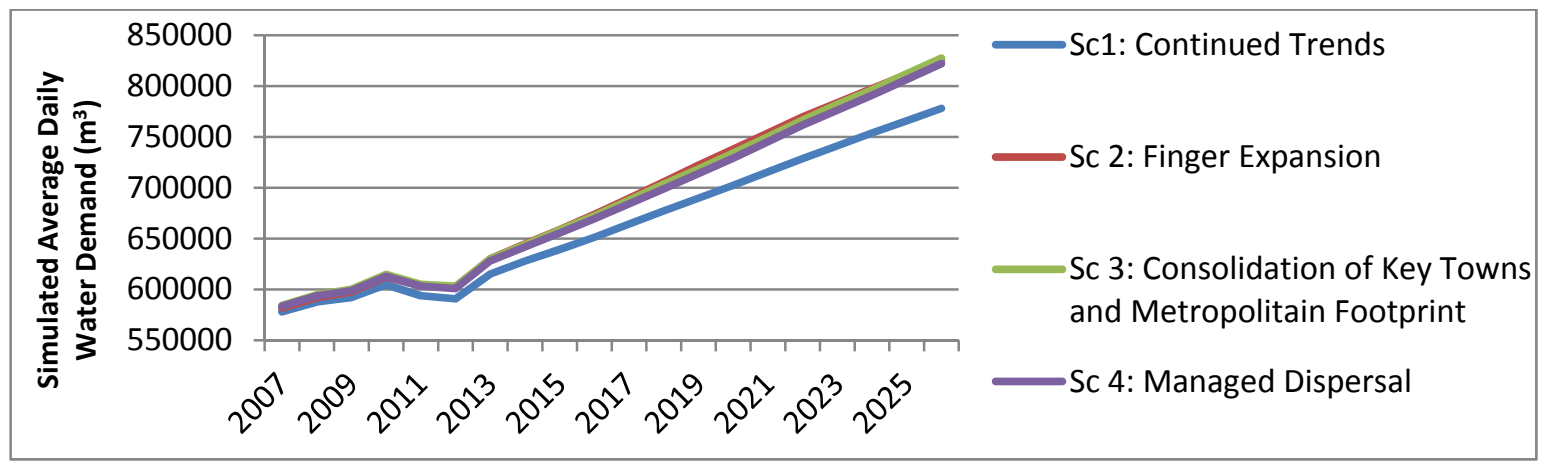

Figure 5: Simulated average daily water demand from 2007 - 2026 for scenarios 1-4

\subsection{Runoff Response to Land-Cover Change Scenarios}

Resulting from increases in impervious surface area, urban growth results in increased stormwater runoff volumes. Following the approach of Franczyk \& Chang (2009) and Lee et al. (2010) we will use mean runoff depth as an indicator for changes in runoff patterns due to surface cover changes. Mean runoff depth is the water depth covering the study area if all of the mean runoff over a time period was distributed evenly over the area.

As shown in figure 6, the pattern of change in runoff between the scenarios is similar to changes in water demand. Stormwater runoff will increase by $27.1,31.8,30.9$ and $30.7 \%$ in scenarios $1-4$ respectively. The difference between scenario one and the remaining scenarios is about $8 \%$, indicating significantly smaller volume of stormwater runoff within the GDWSA due to dispersed development.

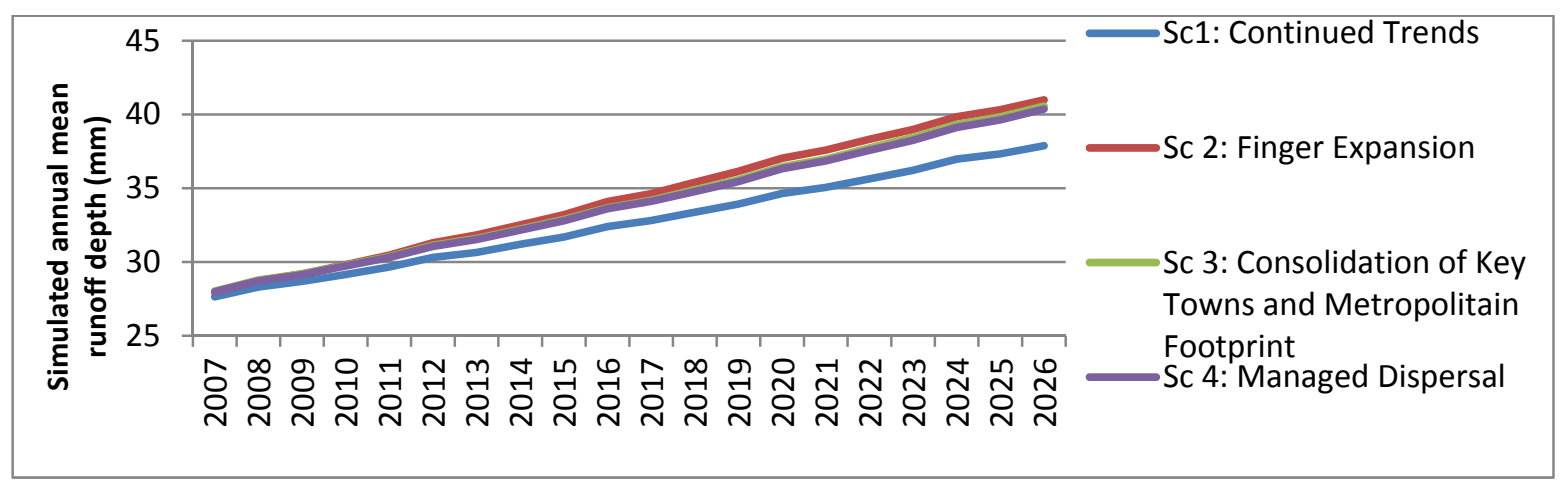

Figure 6: Simulated annual mean runoff depth from $2007-2026$ for scenarios $1-4$ 
Willuweit et al., Modeling the effects of urban growth scenarios on water demand and runoff patterns in Dublin, Ireland

\section{DISCUSSION AND CONCLUSIONS}

The results show that water demand and runoff will increase significantly and will continue to put increasing pressure on urban water infrastructure over the modeled period regardless of the scenario. However, of the scenarios analyzed in this study, the dispersed development is the most favorable outcome from a water demand, cost and runoff perspective within the GDWSA. It is however the least favorable from a policy perspective. It has been shown that reinforcing the implementation of the policies described in the regional planning guidelines can have a compounding effect on the urban water demand and runoff in the GDWSA. Urban water managers and urban and regional planners need to take such potential impacts into account when developing long term strategies for urban water infrastructure.

All four scenarios used in this study represent low growth scenarios, assuming that the current economic downturn will be ongoing until 2026. The study therefore is limited to assessing the effect of differing regional planning policies. Future research should assess the effects of different economic scenarios (such as recession and boom) and their effect on the urban water cycle. Furthermore, all scenarios were based on medium to low density development patterns. Assessing the effects of different urban structure such as compact (high density) vs. dispersed (low density) development should be assessed. Finally, future research will incorporate the combined effect of urban development and climate change impacts on runoff patterns, by using IPCC scenarios to estimate changes in future precipitation and evaporation patterns.

\section{ACKNOWLEDGEMENTS}

This study is funded by the Irish Research Council for Science, Engineering and Technology (IRCSET). The authors would also like to thank the Dublin City, South Dublin, Dun Laoghaire Rathdown and Fingal City councils as well as RPS Ireland for making available the data required for this project.

\section{REFERENCES}

Brennan, M., Shahumyan, H., Walsh, C., Carty, J., Williams, B., \& Convery, S. (2009). Regional Planning Guideline Review: Using MOLAND as part of the Strategic Environmental Assessment Process. Retrieved from www.uep.ie

Convery, F., McInerney, D. O., Sokol, M., \& Stafford, P. (2006). Organising Space in a Dynamic Economy - insights for policy from the Irish experience. Built Environments, 32, $172-183$.

CSO. (2012). Census 2011 - Population Classified by Area. Dublin. Retrieved from http://www.cso.ie/en/media/csoie/census/documents/census2011vollandprofile1/Census 2011 - Population Classified by Area.pdf

DCC. (2010). The Plan, Water Supply Project - Dublin Region. Retrieved from http://www.watersupplyprojectdublinregion.ie/uploads/The Plan (low res).pdf

DELG. (2002). The National Spatial Strategy 2002 - 2020: People, Places, Potential. Dublin.

DOEHLG. (2006). Regulatory Impact Assessment.

DRAMERA. (1999). Strategic Planning Guidelines for the Greater Dublin Area. Dublin.

Engelen, G., Lavalle, C., Barredo, J. I., Meulen, M. van der, \& White, R. (2007). The MOLAND modelling framework for urban and regional land-use dynamics. Modelling Land-Use Change (pp. 297-320). Springer.

Franczyk, J., \& Chang, H. (2009). The effects of climate change and urbanization on the runoff of the Rock Creek basin in the Portland metropolitan area, Oregon, USA. Hydrological Processes, 815(November 2008), 805-815. doi:10.1002/hyp

GDSDS. (2005). Overall Policy Document.

Lee, J., Pak, G., Yoo, C., Kim, S., \& Yoon, J. (2010). Effects of land use change and water reuse options on urban water cycle. Journal of Environmental Sciences, 22(6), 923-928. doi:10.1016/S1001-0742(09)60199-6

Niemczynowicz, J. (1999). Urban hydrology and water management - present and future challenges. Urban Water, 1(1), 1-14.

OECD. (2012). OECD Environmental Outlook to 2050: The Consequences of Inaction. Retrieved from http://www.oecd.org/environment/indicators-modelling-outlooks/oecdenvironmentaloutlookto2050theconsequencesofinaction.htm

Pataki, D. E., Boone, C. G., Hogue, T. S., Jenerette, G. D., McFadden, J. P., \& Pincetl, S. (2011). Socio-ecohydrology and the urban water challenge. Ecohydrology, 4(2), 341-347.

Racsko, P., Szeidl, L., \& Semenov, M. (1991). A serial approach to local stochastic weather models. Ecological modelling, 57(1), 2741.

RPGO. (2010). Regonal Planning Guidelines for the Greater Dublin Area 2010 - 2022. Dublin.

Semenov, M. A., \& Barrow, E. M. (1997). Use of a stochastic weather generator in the development of climate change scenarios. Climatic change, 35(4), 397-414.

Semenov, M., \& Stratonovitch, P. (2010). Use of multi-model ensembles from global climate models for assessment of climate change impacts. Climate Research, 41, 1-14. Retrieved from http:/www.int-res.com/abstracts/cr/v41/n1/p1-14/

Shahumyan, H., White, R., Twumasi, B. O., Convery, S., Williams, B., Critchley, M., Carty, J., et al. (2009). The MOLAND Model Calibration and Validation for the Greater Dublin Region Dublin Region. Dublin. Retrieved from http://www.uep.ie/downloads/index.php?area=document\&category=35

UN. (2010). World population prospects - The 2006 Revision. Futuribles (Paris, France: 1981) (Vol. III). Retrieved from http://www.ncbi.nlm.nih.gov/pubmed/12347200

UN. (2012). World Urbanisation Prospects - The 2011 Revision. Retrieved from http://esa.un.org/unpd/wup/index.htm

UNEP. (2008). Freshwater use by sector at the beginning of the 2000 s. Retrieved from http://www.unep.org/dewa/vitalwater/article48.html

Willuweit, L., \& O'Sullivan, J. J. (n.d.). A decision support tool for sustainable planning of urban water systems: Presenting the Dynamic Urban Water Simulation Model. Water Research. 